Brazilian Journal

of Chemical

Engineering

\title{
In situ DEPOSITION OF COPPER NANOPARTICLES ON POLYETHYLENE TEREPHTHALATE FILTERS AND ANTIBACTERIAL TESTING AGAINST Escherichia coli AND Salmonella enterica
}

\author{
Vinh Tien Nguyen ${ }^{1}$ and Khanh Son Trinh ${ }^{1 *}$ \\ ${ }^{1}$ Ho Chi Minh City University of Technology and Education, Faculty of Chemical and Food Technology, Ho Chi Minh City, Vietnam. \\ ORCID: 0000-0002-1863-4138; E-mail: sontk@hcmute.edu.vn, khanhson96@gmail.com - ORCID: 0000-0002-6365-2693
}

(Submitted: April 18, 2019 ; Revised: August 13, 2019 ; Accepted: August 20, 2019)

\begin{abstract}
This study reports a synthesis of copper nanoparticles (CuNP) deposited on polyethylene terephthalate (PET) filters and antibacterial evaluation of the obtained filters against Escherichia coli and Salmonella enterica. CuNP were synthesized by a two-step method involving adsorption of $\left[\mathrm{Cu}(\mathrm{OH})_{4}\right]^{2-}$ ions onto a PET filter and subsequent chemical reduction by ascorbic acid without using other capping agents. The synthesized CuNP were $105 \pm 26 \mathrm{~nm}($ mean $\pm \mathrm{SD})$ in size and agglomerated into clusters on the PET fibres. Increasing the immersion time of the filters in $\left[\mathrm{Cu}(\mathrm{OH})_{4}\right]^{2-}$ solutions yielded higher amounts of deposited CuNP. SEM images and mass measurements revealed significant changes in the PET fibre surface under the alkaline medium. Passing bacterial suspensions of E. coli and S. enterica through the CuNP-deposited PET filter reduced them by 5.55 and $2.30 \log$ values, respectively. This method of depositing CuNP onto PET material may be further developed for a wide scope of applications, not only in antibacterial filters, but also in catalytic, packaging and biomedical fields. Keywords: Copper nanoparticles; PET; Escherichia coli; Salmonella enterica.
\end{abstract}

\section{INTRODUCTION}

Copper has been used as a biocide in many cultures in medicine and personal care products for more than a thousand years (Milanino, 2006). Nowadays soluble copper salts are used as bactericides in paints, disinfecting surfaces (Cooney, 1995), on ship hulls to reduce biofilm formation (Cooney and Tang, 1999), in agriculture as an algaecide, fungicide, or molluscicide (Lamichhane et al., 2018). Copper can inactivate a variety of enveloped and nonenveloped viruses, such as bacteriophages (Yahaya et al., 2001), bronchitis virus (Jordan and Nassar, 1971), poliovirus, herpes simplex virus (Sagripanti et al., 1993), and HIV-1 (Sagripanti and Lightfoote, 1996).

High antibacterial activities of metallic copper nanoparticles (CuNP) are due to their high surfaceto-volume ratios, which result in direct destructive effects on bacterial membranes and the release of copper ions into solution (Ruparelia et al., 2008; Chatterjee et al., 2014). However, small sizes of nanoparticles may make them readily washed away. Therefore, different materials were used as supports to immobilize CuNP, such as porous ceramics (Klein et al., 2013), natural cellulose (Cady et al., 2011), blotting papers (Dankovich and Smith, 2014). However, the disadvantage of these materials is their low mechanical strength; so in this study, we chose polyester fibres made from polyethylene terephthalate (PET) (Figure 1) as a matrix to incorporate CuNP. Another advantage of polyester fibres is the ease of their modification, especially by alkaline treatment (Penn and Wang, 1994). Aqueous sodium hydroxide solution partially hydrolyses polyester fibres to form carboxylate anions, thus increasing the wettability of the fibres, as well as roughening and pitting their

\footnotetext{
*Corresponding author: Khanh Son Trinh - E-mail: sontk@hcmute.edu.vn, khanhson96@gmail.com
} 


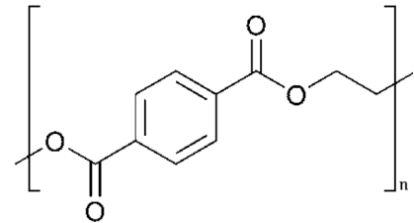

Figure 1. Chemical structure of polyethylene terephthalate (PET).

surface (Dave et al., 1987; Zeronian and Collins, 1989). Another reason for choosing PET material was its wide use in food packaging, especially for soft drink bottling. Success in impregnating antibacterial copper into PET, therefore, would have wide applicability.

Besides the choice of polymeric material for CuNP incorporation, the synthetic method is another important aspect to consider. Many studies have reported incorporation of inorganic nanomaterials into polymers by complicated or cost-ineffective methods for antibacterial surfaces, such as coating CuNP onto polypropylene (PP) by magnetron sputter (Wei et al., 2008), attaching $\mathrm{TiO}_{2}$ nanoparticles to fabrics by grafting with polycarboxylic acids (Meilert et al., 2005), melt-mixing silver-based nanocomposites and polymer powder (Dastjerdi et al., 2008), argon plasma grafting $\mathrm{SiO}_{2}$ nanoparticles on wool surface (Wang et al., 2007), reducing metallic salts inside the polymeric matrix by UV irradiation (Won et al., 2004) and silver chemical plating on polyester and cotton blended fabric (Jiang et al., 2007). CuNP were embedded onto PET fabrics by a complicated three-step process: padding the fabric with chilled $\mathrm{NaBH}_{4}$ solution, subsequent padding with metal precursor solution and curing at $180{ }^{\circ} \mathrm{C}$ for 60 seconds (Chattopadhyay and Patel, 2014).

In our study, we used a simple wet chemical process to produce CuNP on the surface of PET filter: simultaneous alkaline modification of the PET fibre surface and adsorption of copper precursor ions onto it and subsequent in situ reduction of the adsorbed copper precursor by ascorbic acid. Ascorbic acid was chosen because of its ability to reduce copper ions to metallic copper, nontoxicity and environmental sustainability (Xiong et al., 2011). The obtained CuNP/PET filters were then tested for antibacterial performance against pathogenic Escherichia coli and Salmonella enterica.

\section{MATERIALS AND METHODS}

Most of the materials and methods used in this study were described by us in an earlier publication and therefore we partly reproduce its wording (Nguyen and Trinh, 2018).

\section{Materials}

PET filter fabric was purchased from Nguyen Muon Ltd. (Vietnam), with the characteristics shown in Table 1.
Table 1. Physical parameters of PET filter.

\begin{tabular}{cc}
\hline Parameter & Value \\
\hline Average pore size & $25 \mu \mathrm{m}$ \\
Thickness & $2 \mathrm{~mm}$ \\
Grammage & $370 \mathrm{~g} / \mathrm{m}^{2}$ \\
Warp/weft & $60 / 70$ \\
Tensile strength $(\mathrm{N} / \mathrm{cm})$ & $800 / 1000$ \\
Working $\mathrm{pH}$ & $4-7$ \\
Working temperatures & $<150^{\circ} \mathrm{C}$ \\
\hline
\end{tabular}

E. coli VTCC-B-482 and S. enterica VTCC-B-480 strains were purchased by the Microorganisms Bank from the Institute of Microbiology and Biotechnology, Hanoi National University. $\mathrm{CuSO}_{4} .5 \mathrm{H}_{2} \mathrm{O}, \mathrm{NaOH}$, L-ascorbic acid, $\mathrm{H}_{2} \mathrm{O}_{2}, \mathrm{H}_{2} \mathrm{SO}_{4}$ were purchased from Xilong Scientific Ltd. (China).

\section{Preparation of CuNP-deposited PET (CuNP/PET) filter}

CuNP were synthesized and incorporated onto PET filters based on a method originally described by Dankovich with some modifications (Dankovich and Smith, 2014). $90 \mathrm{~mL}$ of $10 \mathrm{M} \mathrm{NaOH}$ solution was added to $10 \mathrm{~mL}$ of $0.5 \mathrm{M} \mathrm{CuSO}_{4}$ to convert $\mathrm{Cu}^{2+}$ ions to complex ions $\left[\mathrm{Cu}(\mathrm{OH})_{4}\right]^{2-}$. Circular pieces of PET filter (diameter $25 \mathrm{~mm}$ ) were immersed in $50 \mathrm{~mL}$ of freshly prepared $\left[\mathrm{Cu}(\mathrm{OH})_{4}\right]^{-2}$ solution for different periods of time. They were then immersed in $50 \mathrm{~mL}$ of ascorbic acid solution, which was continuously shaken at $80{ }^{\circ} \mathrm{C}$ for 20 minutes. Subsequently, the filters were washed four times with $150 \mathrm{~mL}$ of distilled water to remove excess acid and loosely bound copper particles.

\section{Quantitative analysis of deposited copper on CuNP/ PET filters}

Each CuNP/PET filter was put in a beaker containing $6 \mathrm{~mL}$ of $1 \mathrm{M} \mathrm{H}_{2} \mathrm{SO}_{4}$ and $6 \mathrm{~mL}$ of $30 \% \mathrm{H}_{2} \mathrm{O}_{2}$. The solution was then heated to boiling and kept for 10 minutes to completely dissolve the deposited metallic copper

$\mathrm{Cu}+2 \mathrm{H}^{+}+\mathrm{H}_{2} \mathrm{O}_{2} \rightarrow \mathrm{Cu}^{2+}+2 \mathrm{H}_{2} \mathrm{O}$

Copper concentration in the supernatant solution was then determined by Inductively Coupled Plasma Optical Emission Spectroscopy (ICP-OES) according to Standard Methods for the Examination of Water and Waste Water (Rice et al., 2012). The content of CuNP on PET filters was calculated by dividing the total amount of copper (mg) in the supernatant solution by the area of one side of the circular filter $\left(\mathrm{mm}^{2}\right)$. Each measurement was conducted in triplicate.

\section{Sizes and size distribution of CuNP on the filter}

Morphology and sizes of CuNP on the filter were determined by scanning electron microscopy (SEM). To calculate the size distribution of CuNP, we used 
ImageJ software to measure the sizes of 800 different particles in the micrographs and built a size distribution plot based on these values. Along with SEM, we also used Energy-Dispersive X-ray Spectra to confirm the deposition of copper on the filter.

\section{Evaluating antimicrobial activity of the CuNP/PET filter}

The antibacterial activity of the filter was tested against Gram-negative bacteria $S$. enterica and E. coli. The suspension of bacteria cells had a final density of $10^{6} \mathrm{CFU} / \mathrm{mL}$ (6 log value) in phosphate buffered saline (PBS) solution. The filters were first disinfected by washing with $75 \%$ ethanol and then dried in an oven at $100{ }^{\circ} \mathrm{C}$ for 1 hour. $10 \mathrm{~mL}$ of distilled water contaminated with bacteria was passed through the filter with a rate of $3.4 \mathrm{~mL} / \mathrm{min}$. The filter was then washed by filtering $10 \mathrm{~mL}$ of sterilized distilled water. The combined filtrates were then diluted by different factors, incubated on nutrient broth agar at $37{ }^{\circ} \mathrm{C}$ for 24 hours, and then analyzed for surviving bacteria by manually counting formed colonies and multiplied by the dilution factor. Control experiments were also carried out by injecting the E. coli strain through a CuNP-free filter and showed no decrease in bacterial density.

Percentage of inactivation was calculated by the following formula:

$\mathrm{H}+\frac{\mathrm{A}_{1}-\mathrm{A}_{2}}{\mathrm{~A}_{1}} \times 100 \%$

whereH is the inactivation percentage (\%); $\mathrm{A}_{1}$ is the initial concentration of untreated bacterial dispersion $(\mathrm{CFU} / \mathrm{mL}) ; \mathrm{A}_{2}$ is the concentration of filtered bacterial dispersion $(\mathrm{CFU} / \mathrm{mL})$.

\section{RESULTS AND DISCUSSION}

The idea of using a highly alkaline medium to synthesize CuNP was adapted from Dankovich (Dankovich and Smith, 2014). They used alkaline complex $\left[\mathrm{Cu}(\mathrm{OH})_{4}\right]^{2-}$ solution to treat cellulosic paper, but we suppose that this method would work well with polyester materials, including PET, because ester bonds hydrolysing in alkaline medium produce carboxylate groups, which may coordinate with copper ions and keep them stronger on the polymer fibres.

\section{Chemical aspect of the process of $\mathrm{CuNP}$ synthesis}

When excess $10 \mathrm{M} \mathrm{NaOH}$ solution was added to $\mathrm{CuSO}_{4}$ solution, initially blue precipitate $\mathrm{Cu}(\mathrm{OH})_{2}$ formed and then partly turned into soluble $\left[\mathrm{Cu}(\mathrm{OH})_{4}\right]^{2-}$ complex.

$\mathrm{Cu}^{2+}+2 \mathrm{OH}^{-} \rightarrow \mathrm{Cu}(\mathrm{OH})_{2}$

$$
\mathrm{Cu}(\mathrm{OH})_{2}+2 \mathrm{OH}^{-} \rightarrow\left[\mathrm{Cu}(\mathrm{OH})_{4}\right]^{2-}
$$

When the PET filter was immersed in this solution, $\left[\mathrm{Cu}(\mathrm{OH})_{4}\right]^{2-}$ complex ions adsorbed onto their fibres and could serve as a precursor for CuNP. Subsequent immersion of the filter in $1 \mathrm{M}$ ascorbic acid solution initially produced $\mathrm{Cu}(\mathrm{OH})_{2}$ deposited on the filter surface. $\mathrm{Cu}(\mathrm{OH})_{2}$, was further reduced by ascorbic acid to $\mathrm{Cu}$ particles according to the mechanism in Figure 2.

In this two-step mechanism, ascorbic acid acts as an electron donor toward $\mathrm{Cu}(\mathrm{OH})_{2}$ and then $\mathrm{Cu}_{2} \mathrm{O}$, resulting in their reduction (Du et al., 2012; Liu et al., 2012).

The progress of the colour change of the PET filter during these synthetic steps is demonstrated in Figure 3 . The white filter (a), after being immersed in the $\left[\mathrm{Cu}(\mathrm{OH})_{4}\right]^{2-}$ solution adsorbed these ions and turned blue (b). After 120 minutes of immersion in $1 \mathrm{M}$ ascorbic acid solution, the blue filter (b) turned brownorange (c) due to the formation of CuNP.

$$
\text { L-Ascorbic Acid }
$$

Figure 2. Two-step chemical reduction of $\mathrm{Cu}(\mathrm{OH})_{2}$ by ascorbic acid.

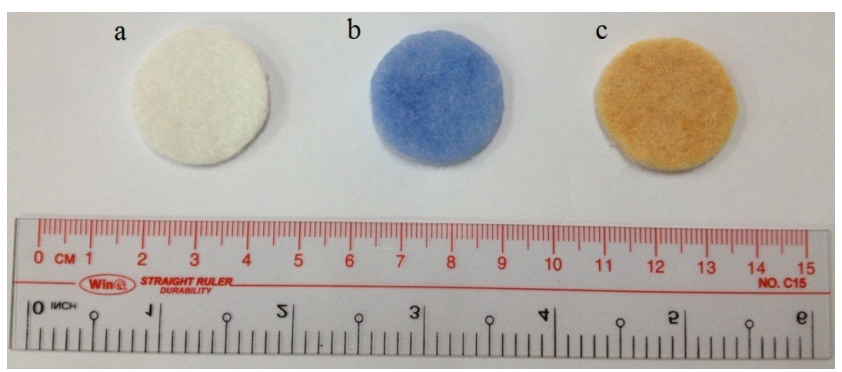

Figure 3. Pieces of PET filter before treatments (a), after absorbing $\left[\mathrm{Cu}(\mathrm{OH})_{4}\right]^{2-}$ (b) and after depositing CuNP (c).

Influence of the time of immersion in $\left[\mathrm{Cu}(\mathrm{OH})_{4}\right]^{2-}$ solution on the copper content deposited on PET filter

Figure 4 shows the final CuNP/PET filters with different immersion time in $\left[\mathrm{Cu}(\mathrm{OH})_{4}\right]^{2-}$ solution. Visually, although there were few differences in the colours of these filters, the one with 120 minutes of immersion time was the most intense in colour. The copper content on these filters, determined by ICPOES, showed that 120 minutes of immersion yielded 


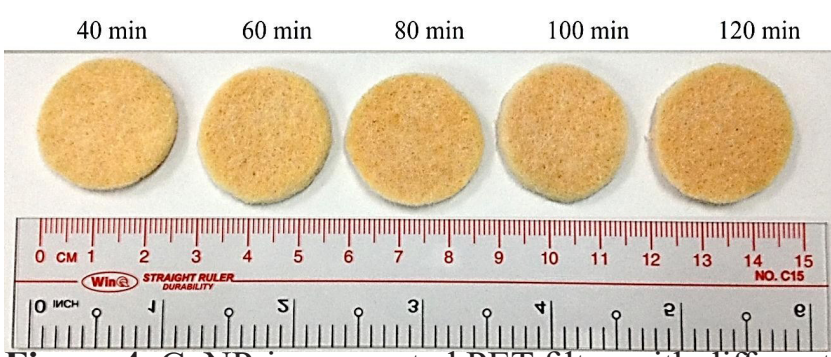

Figure 4. CuNP-impregnated PET filter with different immersion time in $\left[\mathrm{Cu}(\mathrm{OH})_{4}\right]^{2-}$.

the highest content of copper on the CuNP/PET filters (Figure 5).

Although longer immersion time in $\left[\mathrm{Cu}(\mathrm{OH})_{4}\right]^{2-}$ solution could produce more copper, our preliminary tests showed that, after about 140 minutes of immersion, the PET fibres were heavily degraded and broken apart. So we decided to use CuNP/PET filters with 120 minutes of immersion time for subsequent antibacterial tests. Comparison with $\mathrm{CuNP}$ content in another research $\left(0.16 \mu \mathrm{g}\right.$ on $78.5 \mathrm{~mm}^{2}$ or $0.00020 \mathrm{mg} /$ $\mathrm{cm}^{2}$ ) on impregnating CuNP onto PET fabric using $\mathrm{NaBH}_{4}$ as reducing agent showed that our contents of copper $\left(0.096 \mathrm{mg} / \mathrm{cm}^{2}\right)$ were about 500 times higher (Chattopadhyay and Patel, 2014). It should be noted that we used a $\mathrm{CuSO}_{4}$ concentration only 50 times higher than that in the mentioned study, with the same $\mathrm{CuSO}_{4} /$ reducing agent concentration ratio (1:2).

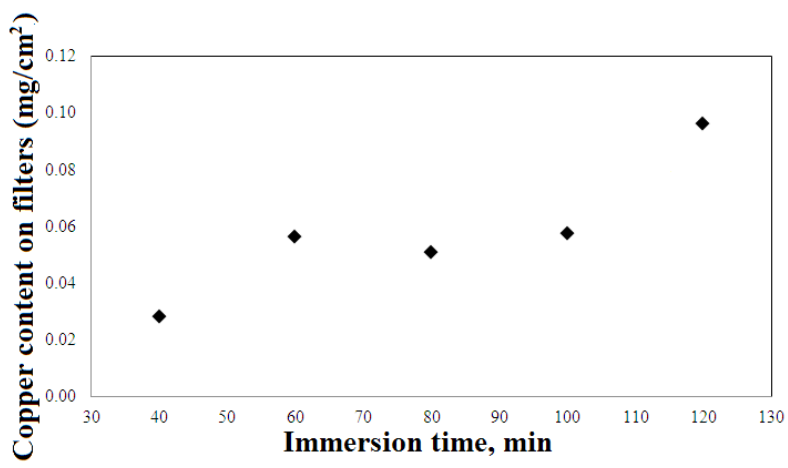

Figure 5. Copper contents on PET filters with different immersion times in $\left[\mathrm{Cu}(\mathrm{OH})_{4}\right]^{2-}$ solution.

\section{Hydrolysis of PET filter fibres in alkaline $10 \mathrm{M}$ $\mathrm{NaOH}$ solution}

As mentioned in the introduction, the highly alkaline medium in the $\left[\mathrm{Cu}(\mathrm{OH})_{4}\right]^{2-}$ solution would attack the surface of PET fibres. The ester groups on the surface of the PET fibres react with hydroxide ions, resulting in breakage of the polymer backbone and formation of carboxylate groups on the chain (Figure 6) (Zeronian and Collins, 1989). This hydrolysis process would also result in the formation of ethylene glycol and soluble short-chain fragments from the polyester fibres, thus reducing their weight.

To confirm this hypothesis, we immersed PET filters in $10 \mathrm{M} \mathrm{NaOH}$ solution at room temperature<smiles>CC(C)OC(=O)c1ccc(C(=O)Oc2ccc(OCc3ccc(OCCO)cc3)cc2)cc1</smiles>

Figure 6. Hydrolysis of PET in aqueous $\mathrm{NaOH}$ solution.

and measured their mass losses over time (Figure 7), as well as examined the surface of PET fibres by using scanning electron microscopy (Figure 8 ). The weight

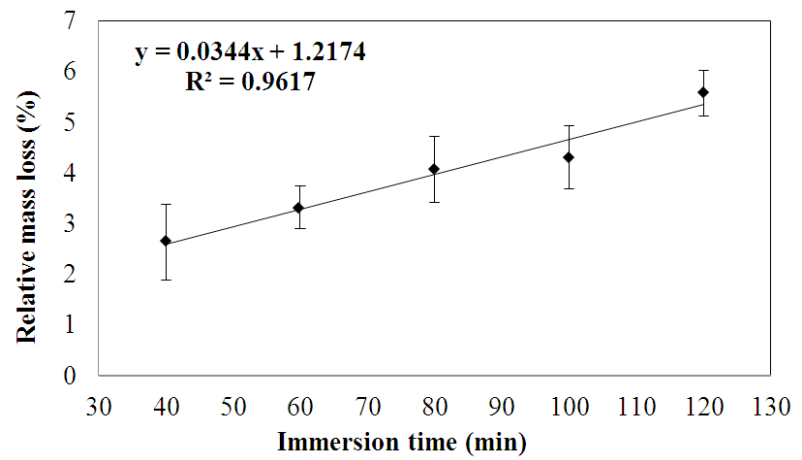

Figure 7. Relative mass losses of PET filter immersed in $10 \mathrm{M} \mathrm{NaOH}$ solution.

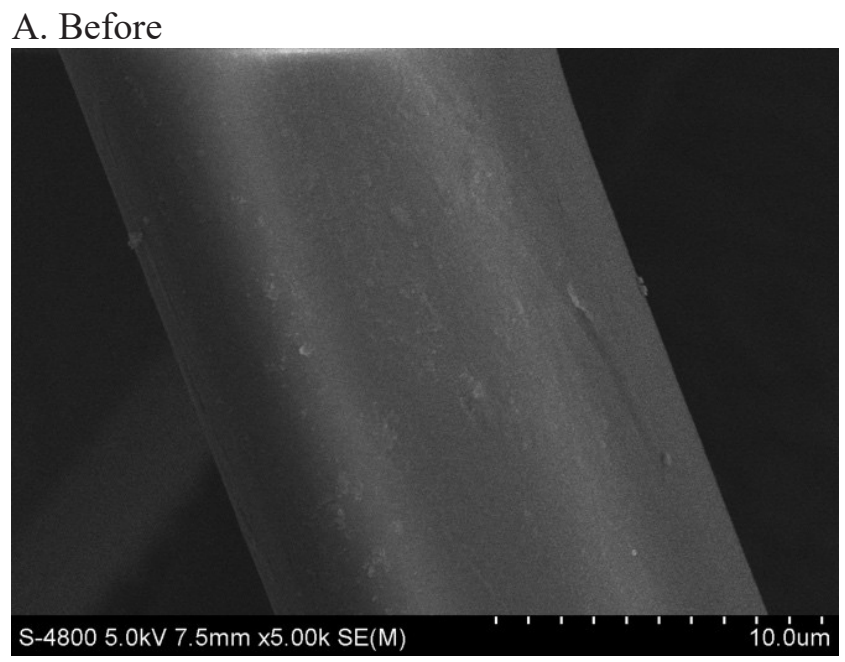

B. After

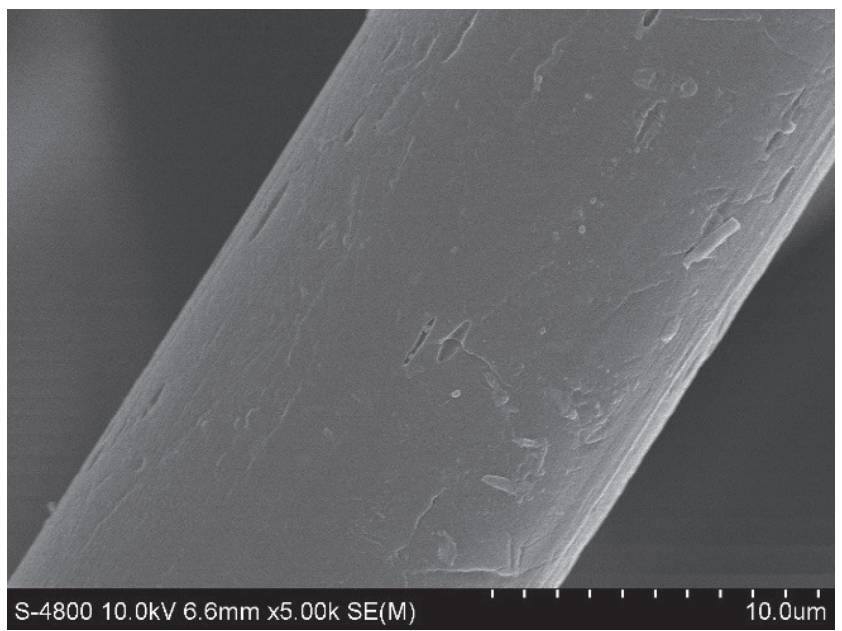

Figure 8. The surface of PET fibre before (a) and after (b) immersing in $10 \mathrm{M} \mathrm{NaOH}$ for 120 minutes. 
loss exhibited a nearly linear relationship on the investigated time scale, which indicated the constant rate of hydrolysis of about $0.034 \% / \mathrm{min}$. Totally, a $5.2 \%$ weight loss was identified after hydrolysis for $120 \mathrm{~min}$.

SEM micrographs showed morphological differences of the PET fibres before and after treatment with $\mathrm{NaOH}$ solution. Highly alkaline medium hydrolysed a part of the fibre surface, producing many scratches and holes. We suppose that these damages on the surface are one of the main reasons for the high copper content on the filter after the reduction step with ascorbic acid. Hydrophilic carboxyl and hydroxyl groups at these places can improve the wettability of the fibres, as well as their adsorbing capability toward copper ions (Zeronian and Collins, 1989). Moreover, the scratches and holes may shield the deposited CuNP better from the following washing steps.

\section{Morphology and size distribution of CuNP on PET filters}

The energy-dispersive X-ray (EDX) spectrum of an area on the surface of PET fibres after reducing the adsorbed $\left[\mathrm{Cu}(\mathrm{OH})_{4}\right]^{2-}$ with ascorbic acid confirmed the presence of copper on the PET filter (Figure 9).

SEM micrographs at different magnifications of a CuNP/PET fibre (Figure 10) show that CuNP aggregated and significantly covered the surface of PET fibres. From these images, it can also be seen that the treatments significantly damaged the surface of PET fibres. Figure 11 shows the statistical analysis of 800 particles from the aggregates, revealing that the synthesized CuNP had sizes of $105 \pm 26 \mathrm{~nm}$ (mean \pm SD).

In this synthesis of CuNP we did not use any capping agent, but the sizes of CuNP were relatively small. The reason was that ascorbic acid at high concentration
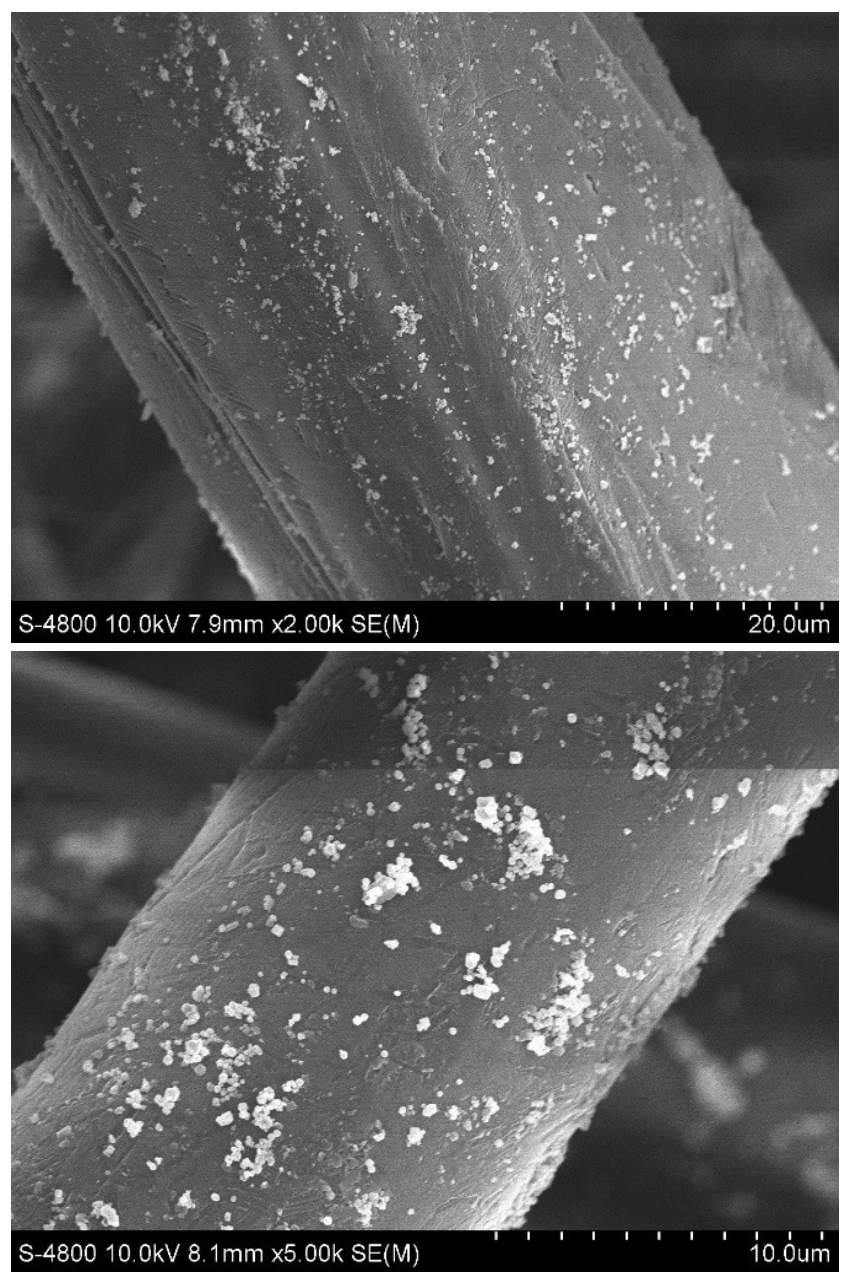

Figure 10. SEM images of a CuNP/PET filter fibre.

(1M) can serve not only as a reducing agent, but also a capping one (Liu et al., 2012). Moreover, immobilization of CuNP on the solid surface of PET fibres decreased the mobility of CuNP nuclei in the nucleation stage and subsequently the chance of their collisions to produce large particles.

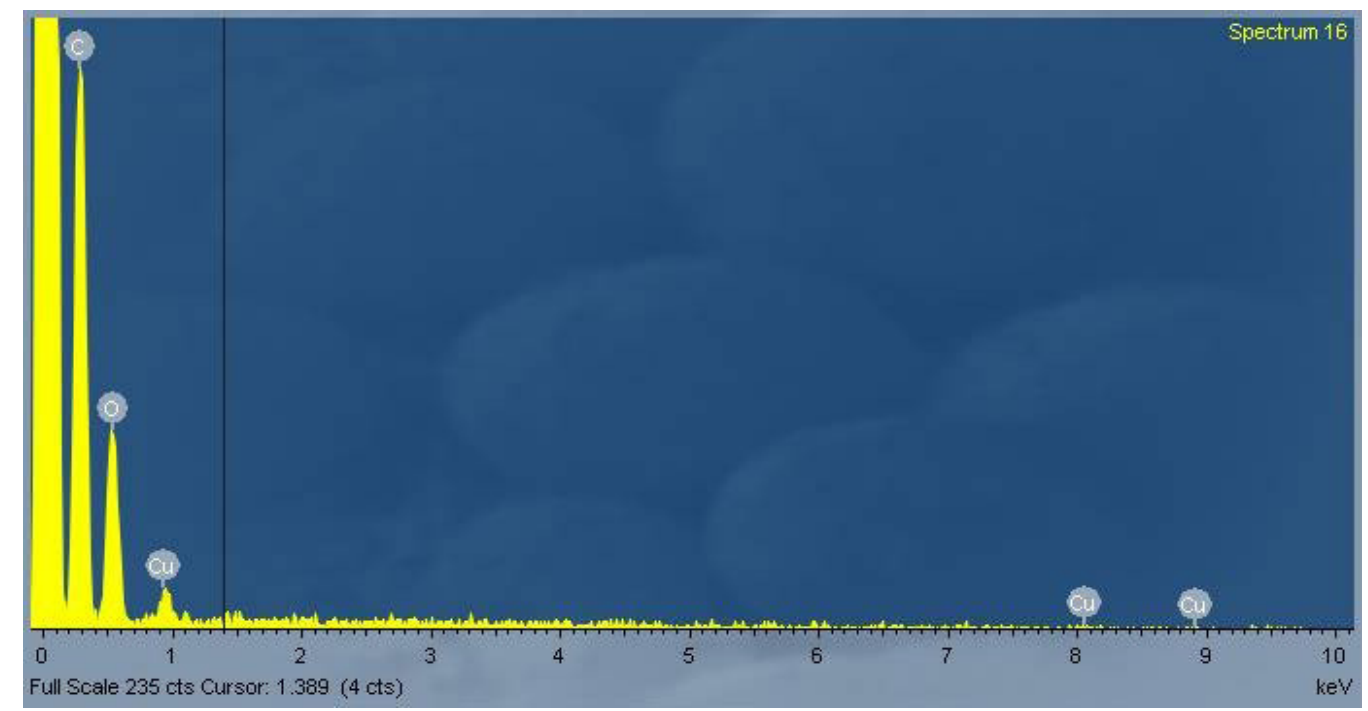

Figure 9. EDX spectrum of an area on the surface of a CuNP/PET fibre. 


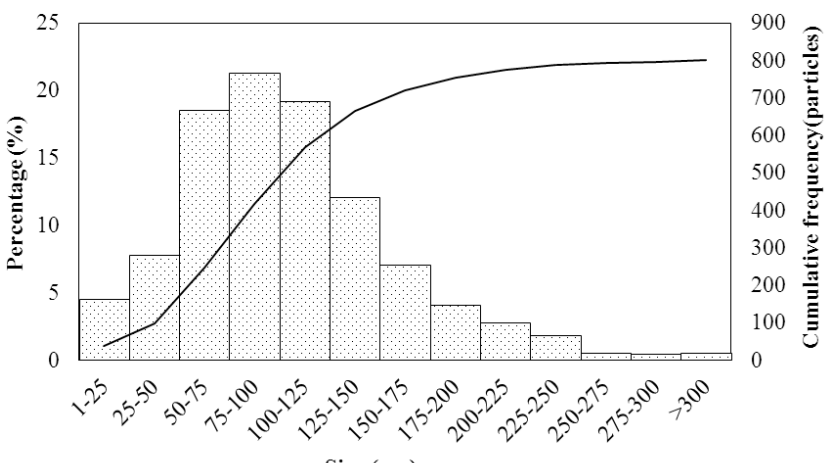

Size (nm)

Figure 11. Size distribution of 800 copper particles on CuNP/PET fibres.

\section{In vitro antibacterial tests against Escherichia coli and Salmonella enterica}

We used CuNP/PET filters with the highest copper content $\left(0.096 \mathrm{mg} / \mathrm{cm}^{2}\right)$ for antibacterial tests. After passing a suspension of bacteria through the CuNP/ PET filter, we incubated the filtrates for 24 hours at $37{ }^{\circ} \mathrm{C}$ and measured the number of colonies grown. Figure 12 displays some representative results for CFU counts and Figure 13 shows how much the CFU density decreased in log-value units.

The results showed that the CuNP/PET filters $\left(0.096 \mathrm{mg} \mathrm{CuNP} / \mathrm{cm}^{2}\right)$ resulted in bacteria inactivation with a 5.55-log reduction for $E$. coli and 2.30$\log$ reduction for $S$. enterica. These values of logreduction corresponded to inactivation percentages of $99.9997 \%$ for $E$. coli and $99.5 \%$ for $S$. enterica. These results were comparatively higher than those from other antibacterial studies in the literature on E. coli with the same bacteria density $\left(10^{6} \mathrm{CFU} / \mathrm{mL}\right)$ (Tamayo et al., 2016). It should be noted that treating E. coli suspensions by passing them through the CuNP/PET filter in our study resulted in higher antibacterial activity ( $99.9997 \%$ for 2 minutes of contact time), compared to immersing a $\mathrm{CuNP} /$ polymer material in the E. coli suspension $(99.9 \%$ for 3 hours of contact time) (Palza et al., 2010).

Although revealing the mechanism of antibacterial activity of our CuNP/PET filter was outside the scope of this research, the literature review suggested some possible pathways leading to the inactivation of the bacteria. Several studies showed that the antibacterial activity of CuNP is related to the release of $\mathrm{Cu}^{2+}$ ions into the medium. These copper ions strongly adsorb onto and damage the bacterial cell membrane, resulting in the loss of membrane integrity and cell death (Hong et al., 2012; Emam et al., 2017). After degrading the cell membrane, copper ions can further penetrate the cell and trigger oxidative stresses under aerobic conditions, leading to damage of lipids, proteins, nucleic acids and DNA degradation (Liochev and Fridovich, 2002; Tong et al., 2005; Santo et al., 2012; Dalecki et al., 2017). Some studies compared
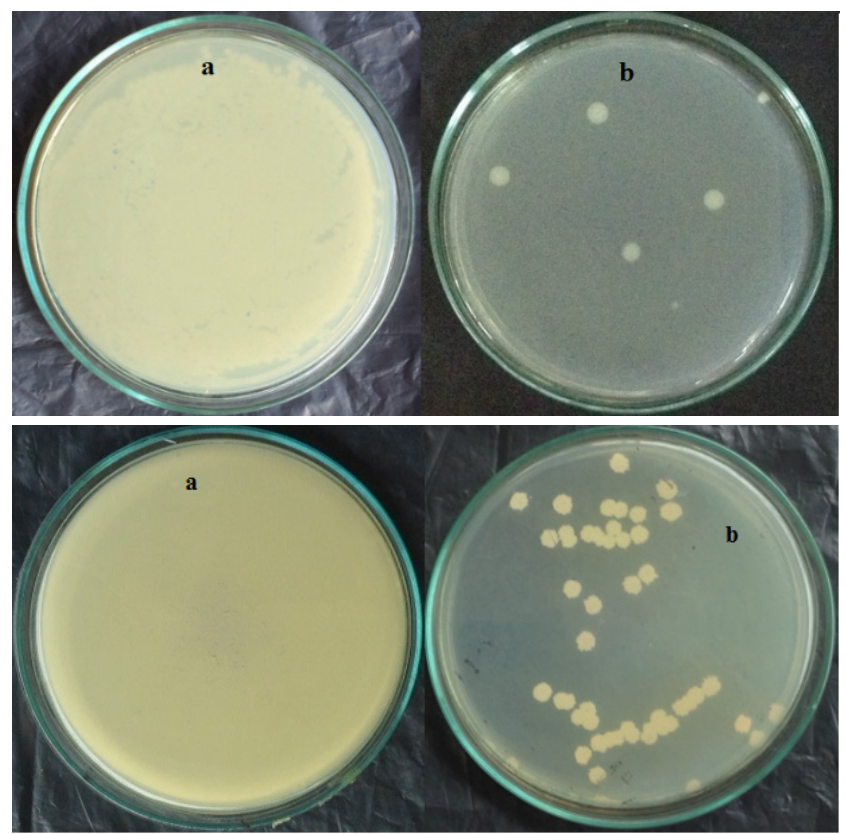

Figure 12. Petri dishes with $E$. coli (upper) and $S$. enterica (lower) colonies before (a) and after (b) passing through CuNP/PET filters.

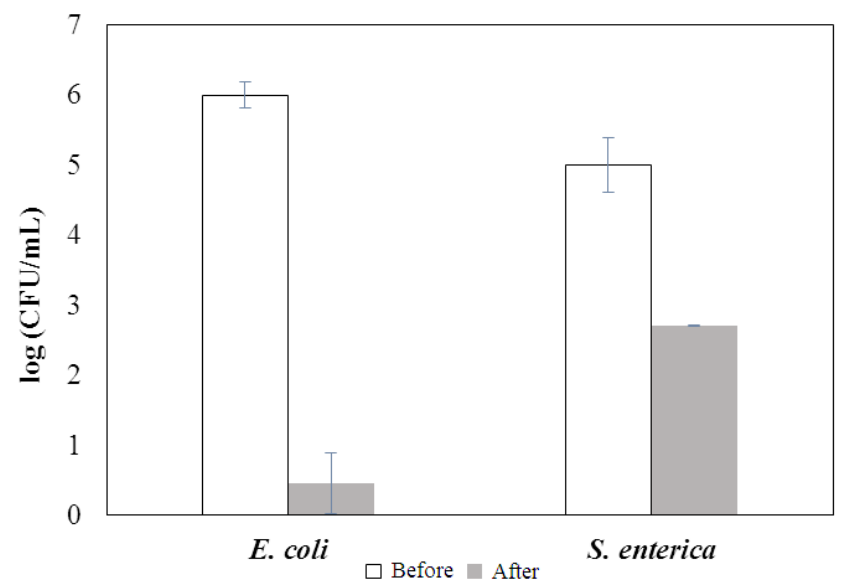

Figure 13. Log reduction of the bacteria $E$. coli and $S$. enterica in suspensions after passing through $\mathrm{CuNP} /$ PET filters.

the antibacterial effects of CuNP and copper salts with the same copper concentrations. They found that the contribution of released copper ions to the bactericidal effect of CuNP might be minor compared to the effect of their nanosize (Chatterjee et al., 2014; Giannousi et al., 2014). The average size of a grown E. coli cell is about 1.0-2.0 $\mu \mathrm{m}$ (Board and Council, 1999), which is more than 10 times higher than the average sizes of CuNP $(105 \pm 26 \mathrm{~nm})$ in our study. This implies that, when the bacteria suspension slowly passed through the CuNP/PET fibres with a high density of CuNP on the surface, bacterial cells had chances to mechanically collide with the CuNP, leading to cell membrane damages and even the formation of some reactive complex between CuNP and organic components 
in the cellular medium (Board and Council, 1999; Chatterjee et al., 2014).

\section{CONCLUSIONS}

In summary, through a two-step synthesis using ascorbic acid as a reducing agent, CuNP coated PET filters were prepared. Through the adsorption on the PET fibres and the reduction in aqueous ascorbic acid, CuNP were embedded on the surface of the filter and fixed by the PET fibre matrix. There was a significant alteration of the fibre surface by the highly alkaline medium in the first step, which may result in a high content of CuNP on the filter. The deposited CuNP were of nanoscale sizes, but mostly agglomerated on the fibre surface. The CuNP/PET filter exhibited a strong and efficient antibacterial activity against $E$. coli and $S$. enterica with 5.55 and 2.30 log-reduction values, respectively. We propose that the rapid antibacterial effect was not only due to the release of $\mathrm{Cu}^{2+}$ ions, but that the direct contact with $\mathrm{CuNP}$ on the filter fibres also played an important role. The obtained $\mathrm{CuNP} / \mathrm{PET}$ fibres material may have a wide scope of applications, not only in antibacterial, but also in catalytic, packaging, and biomedical fields.

\section{ACKNOWLEDGMENTS}

The authors thank Ho Chi Minh City University of Technology and Education for supplying necessary facilities and equipment, as well as financial support to complete this study.

\section{REFERENCES}

Board, S. S., Council, N. R. Size Limits of Very Small Microorganisms: Proceedings of a Workshop. National Academies Press (1999).

Cady, N. C., Behnke, J. L.. Strickland, A. D. CopperBased Nanostructured Coatings on Natural Cellulose: Nanocomposites Exhibiting Rapid and Efficient Inhibition of a Multi-Drug Resistant Wound Pathogen, A. Baumannii, and Mammalian Cell Biocompatibility in Vitro. Advanced Functional Materials, 21, 2506-2514 (2011). https://doi.org/10.1002/adfm.201100123

Chatterjee, A. K., Chakraborty, R., Basu, T. Mechanism of Antibacterial Activity of Copper Nanoparticles. Nanotechnology, 25, 135101 (2014). https://doi. org/10.1088/0957-4484/25/13/135101

Chattopadhyay, D., Patel, B. Nano Metal Particles: Synthesis, Characterization and Application to Textiles, Manufacturing Nanostructures. One Central Press, 184-215 (2014).

Cooney, J. J., Tang, R.-J. Quantifying Effects of Antifouling Paints on Microbial Biofilm Formation. In: Methods in Enzymology: Elsevier, v.310, 1999. p.637-644. ISBN 0076-6879. https:// doi.org/10.1016/S0076-6879(99)10049-1

Cooney, T. E. Bactericidal Activity of Copper and Non-Copper Paints. Infection Control \& Hospital Epidemiology, 16, 444-450 (1995). https://doi. org/10.2307/30141081

Dalecki, A. G., Crawford, C. L., Wolschendorf, F. CopperandAntibiotics: Discovery, Modes ofAction, and Opportunities for Medicinal Applications. In: Advances in Microbial Physiology: Elsevier, v.70, 2017. p.193-260. ISBN 0065-2911. https://doi. org/10.1016/bs.ampbs.2017.01.007

Dankovich, T. A., Smith, J. A. Incorporation of Copper Nanoparticles into Paper for Point-of-Use Water Purification. Water research, 63, 245-251 (2014). https://doi.org/10.1016/j.watres.2014.06.022

Dastjerdi, R., Mojtahedi, M., Shoshtari, A. Processing and Properties of Nanocomposite Filament Yarns with Various Filler Concentrations from Two Different Modification Methods. Macromolecular symposia, 2008, Wiley Online Library. p.154-165. https://doi.org/10.1002/masy.200851421

Dave, J., Kumar, R., Srivastava, H. Studies on Modification of Polyester Fabrics I: Alkaline Hydrolysis. Journal of Applied Polymer Science, 33, 455-477 (1987). https://doi.org/10.1002/ app.1987.070330215

Du, J., Cullen, J. J., Buettner, G. R. Ascorbic Acid: Chemistry, Biology and the Treatment of Cancer. Biochimica et Biophysica Acta, 1826, 443-457 (2012). https://doi.org/10.1016/j. bbcan.2012.06.003

Emam, H. E., Ahmed, H. B., Bechtold, T. In-Situ Deposition of $\mathrm{Cu}_{2} \mathrm{O}$ Micro-Needles for Biologically Active Textiles and Their Release Properties. Carbohydrate Polymers, 165, 255-265 (2017). https://doi.org/10.1016/j.carbpol.2017.02.044

Giannousi, K., Lafazanis, K., Arvanitidis, J., Pantazaki, A., Dendrinou-Samara, C. Hydrothermal Synthesis of Copper Based Nanoparticles: Antimicrobial Screening and Interaction with DNA. Journal of Inorganic Biochemistry, 133, 24-32 (2014). https:// doi.org/10.1016/j.jinorgbio.2013.12.009

Hong, R., Kang, T. Y., Michels, C. A., Gadura, N. Membrane Lipid Peroxidation in Copper AlloyMediated Contact Killing of Escherichia Coli. Appl. Environ. Microbiol., 78, 1776-1784 (2012). https://doi.org/10.1128/AEM.07068-11

Jiang, S., Newton, E., Yuen, C.-W. M., Kan, C.W. Application of Chemical Silver Plating on Polyester and Cotton Blended Fabric. Textile Research Journal, 77, 85-91 (2007). https://doi. org $/ 10.1177 / 0040517507078739$

Jordan, F., Nassar, T. The Influence of Copper on the Survival of Infectious Bronchitis Vaccine Virus in Water. The Veterinary Record, 89, 609-610 (1971). https://doi.org/10.1136/vr.89.23.609 
Klein, T. Y., Wehling, J., Treccani, L., Rezwan, K. Effective Bacterial Inactivation and Removal of Copper by Porous Ceramics with High Surface Area. Environmental Science \& Technology, 47, 1065-1072 (2013). https://doi.org/10.1021/ es3045828

Lamichhane, J. R., Osdaghi, E., Behlau, F., Köhl, J., Jones, J. B., Aubertot, J.-N. Thirteen Decades of Antimicrobial Copper Compounds Applied in Agriculture. A Review. Agronomy for Sustainable Development, 38, 28 (2018). https://doi. org/10.1007/s13593-018-0503-9

Liochev, S. I., Fridovich, I. The Haber-Weiss Cycle-70 Years Later: An Alternative View. Redox Report, 7, 55-57 (2002). https://doi. org/10.1179/135100002125000190

Liu, Q.-M., Yasunami, T., Kuruda, K., Okido, M. Preparation of $\mathrm{Cu}$ Nanoparticles with Ascorbic Acid by Aqueous Solution Reduction Method. Transactions of Nonferrous Metals Society of China, 22, 2198-2203 (2012). https://doi. org/10.1016/S1003-6326(11)61449-0

Meilert, K., Laub, D., Kiwi, J. Photocatalytic Self-Cleaning of Modified Cotton Textiles by Tio2 Clusters Attached by Chemical Spacers. Journal of Molecular Catalysis A: Chemical, 237, 101-108 (2005). https://doi.org/10.1016/j. molcata.2005.03.040

Milanino, R. Copper in Medicine and Personal Care: A Historical Overview, Copper and the skin. New York: Informa Healthcare, 149-60 (2006). https:// doi.org/10.1201/9781420009439-9

Nguyen, V. T., Trinh, K. S. Green Synthesis of Copper Nanoparticles Deposited on Polyester Filter for Antibacterial Applications. 2018 4th International Conference on Green Technology and Sustainable Development (GTSD), 2018, 23-24 Nov. 2018. p.533-537.

Palza, H., Gutiperrez, S., Delgado, K., Salazar, O., Fuenzalida, V., Avila, J. I., Figueroa, G., Quijada, R. Toward Tailor-Made Biocide Materials Based on Poly(Propylene)/Copper Nanoparticles. Macromolecular Rapid Communications, 31， 563-567 (2010). https://doi.org/10.1002/ marc. 200900791

Penn, L., Wang, H. Chemical Modification of Polymer Surfaces: A Review. Polymers for Advanced Technologies, 5, 809-817 (1994). https://doi. org/10.1002/pat.1994.220051207

Rice, E. W., Baird, R. B., Eaton, A. D. Standard Methods for the Examination of Water and Wastewater. American Public Health Association Washington, DC (2012).

Ruparelia, J. P., Chatterjee, A. K., Duttagupta, S. P., Mukherji, S. Strain Specificity in Antimicrobial
Activity of Silver and Copper Nanoparticles. Acta Biomaterialia, 4, 707-716 (2008). https://doi. org/10.1016/j.actbio.2007.11.006

Sagripanti, J. L., Lightfoote, M. M. Cupric and Ferric Ions Inactivate Hiv. AIDS Research and Human Retroviruses, 12, 333-336 (1996). https://doi. org/10.1089/aid.1996.12.333

Sagripanti, J. L., Routson, L. B., Lytle, C. D. Virus Inactivation by Copper or Iron Ions Alone and in the Presence of Peroxide. Applied and Environmental Microbiology, 59, 4374-4376 (1993).

Santo, C. E., Quaranta, D., Grass, G. Antimicrobial Metallic Copper Surfaces Kill Staphylococcus Haemolyticus Via Membrane Damage. Microbiologyopen, 1, 46-52 (2012). https://doi. org/10.1002/mbo3.2

Tamayo, L., Azócar, M., Kogan, M., Riveros, A., Páez, M. Copper-Polymer Nanocomposites: An Excellent and Cost-Effective Biocide for Use on Antibacterial Surfaces. Materials Science and Engineering: C, 69, 1391-1409 (2016). https://doi. org/10.1016/j.msec.2016.08.041

Tong, G., Yulong, M., Peng, G., Zirong, X. Antibacterial Effects of the $\mathrm{Cu}$ (Ii)-Exchanged Montmorillonite on Escherichia Coli K88 and Salmonella Choleraesuis. Veterinary Microbiology, 105, 113-122 (2005). https://doi.org/10.1016/j. vetmic.2004.11.003

Wang, S., Hou, W., Wei, L., Jia, H., Liu, X., Xu, B. Antibacterial Activity of Nano-Sio ${ }_{2}$ Antibacterial Agent Grafted on Wool Surface. Surface and Coatings Technology, 202, 460-465 (2007). https:// doi.org/10.1016/j.surfcoat.2007.06.012

Wei, Q., Yu, L., Wu, N., Hong, S. Preparation and Characterization of CopperNanocomposite Textiles. Journal of Industrial Textiles, 37, 275-283 (2008). https://doi.org/10.1177/1528083707083794

Won, J. O., Kang, Y. S., Jung, B. S., Yoon, Y. S. Composite Polymers Containing Nanometer-Sized Metal Particles and Manufacturing Method Thereof. Patent US6712997B2, United States (2004).

Xiong, J., Wang, Y., Xue, Q., Wu, X. Synthesis of Highly Stable Dispersions of Nanosized Copper Particles Using L-Ascorbic Acid. Green Chemistry, 13, 900-904 (2011). https://doi.org/10.1039/ c0gc00772b

Yahaya, M., Straub, T., Yahaya, M. Inactivation of Poliovirus and Bacteriophage MS-2 in Copper, Galvanised and Plastic Domestic Water Pipes, International Copper Research Association Project, 48 (2001).

Zeronian, S. H., Collins, M. J. Surface Modification of Polyester by Alkaline Treatments. Textile Progress, 20, 1-26 (1989). https://doi. org/10.1080/00405168908688948 